Felicity Wood Kinship, collegiality and witchcraft:

Felicity Wood is Professor in the Department of English at the University of Fort Hare. She has published on the way in which contemporary western and westernised societies partake in mystery, ritual and magic. South African perceptions of sorcery and the occult aspects of contemporary academia Email:fwood@ufh.ac.za

\title{
Kinship, collegiality and witchcraft: South African perceptions of sorcery and the occult aspects of contemporary academia
}

Certain South African perceptions of sorcery acquire new resonance when considered in the context of present-day corporatised, managerially governed higher education. Concepts of witchcraft from elsewhere in Africa further illuminate this. Indeed, there are certain striking metaphorical parallels between distinctive trends in the contemporary market-driven academic environment and various perceptions of witchcraft. These include the connections between kinship and witchcraft; also the belief that greed, jealousy and the selfish accumulation of material resources can be associated with sorcery. This conviction has certain points of comparison with the damaging effects of the impetus towards "individualism, competition and consumption" (Salim Vally) in higher education, stemming from broader trends in globalised corporate capitalism. Thus there are areas of commonality between certain African perceptions of sorcery and the corporatised academic environment. Keywords: corporatisation, kinship, magic, sorcery, universities.

Various views of witchcraft acquire a new resonance when considered in the context of present-day academia, wedded as it is to market forces and subjected to corporate capitalist pressures. This paper explores the metaphorical parallels between certain concepts of sorcery in South Africa and contemporary corporatised, managerially governed university environments. Perceptions of witchcraft from the Cameroon and the South Sudan that have bearing on this are also discussed. ${ }^{1}$ (These latter regions are focused upon in several key studies of witchcraft in Africa, by which this paper is informed.) Furthermore, the havoc that is said to be wrought by malign supernatural agencies, such as the wealth-giving South African mamlambo, is suggestive of the damage that the alliance between higher education and the marketplace has inflicted on corporatised universities. ${ }^{2}$

Jean and John Comaroff (279) describe occult economies: wealth-generating enterprises that partake in aspects of mystery and magic. Contemporary corporatised universities have become occult economies, so this study draws on ethnological research findings and academic critiques of contemporary corporatised universities that illuminate one dimension of this. Certain points that have bearing on one another derive from these diverse sources. Set side by side, they draw two different worlds 
closer together: the market-driven, managerially governed academic environment and the dark domain of the witch.

Innovation, Jean Comaroff maintains, often occurs "in situations of radical structural cleavage—such as result from conquest, proletarianisation or the sudden sharpening of contradictions within hierarchical orders" (253). The market-driven restructuring of many universities in South Africa and elsewhere and the imposition of new managerial systems of governance that enforce this has had consequences of this kind. It has brought about new power structures and intensified existing divisions and contradictions within institutional hierarchies, while heightening tensions and polarities between diverse universities, both locally and internationally. Conditions of this nature have generated various metaphorical parallels with the occult in contemporary academia (Wood "Sorcery"). This study focuses on one dimension of this: the points of comparision between distinctive features of contemporary marketised universities and aspects of witchcraft. ${ }^{3}$

The term "university" is used broadly to denote present-day institutions of higher education that have subjected themselves to marketisation and managerialism, emulating corporate models. Restructuring of this kind has swept through South African higher education since 1990, and through many universities worldwide. Comparable conditions often tend to be prevalent in institutions in countries where neoliberal economic tendencies valorising market forces, globalisation, cost-cutting measures, privatisation, consumerism, competitiveness and profit-making exercise a powerful sway. Although particular reference is made to South African universities, mention is also made of institutions in countries in which the above-delineated dynamics are prevalent.

In 1993, Canadian academic Howard Buchbinder employed the term "market university" to denote institutions that have reconstructed themselves as business enterprises, subjugating themselves to the dictates of free-market capitalism. "Corporate university", a related term, indicates market-oriented institutions that imitate the culture, ethos and procedures of the corporate world; while "managerialism" denotes the new forms of institutional authority that impose and enforce this (see also Thornton 16).

Although both local and global dynamics affect the higher education systems in different countries in diverse ways, a number of important points of comparison exist globally. To varying degrees and in various respects, contemporary corporatised universities have certain key features in common. Thus, it becomes harder to consider one specific country's higher education system in isolation.

For example, as South African universities were remade as market-oriented enterprises, particular countries whose systems of higher education have been substantially reconfigured in accordance with international neoliberal trends have guided this process. For instance, the changes in South African higher education were substantially influenced by the restructuring of the UK universities, implemented 
under Thatcher and then New Labour, so particular mention is made of universities in that country. Then, commercialised university models in the USA have also exerted a powerful influence, both locally and internationally (Wood "Occult Innovations" and "Faustian Pacts"). The forms of corporatisation and managerialism in South African universities have also been shaped by market-driven Australian models.

We now turn to the darker dimensions of restructured, corporatised universities in South Africa and elsewhere.

\section{Faust, the mamlambo and higher education}

There are certain parallels between the market-oriented restructuring of higher education and Christopher Marlowe's version of the tale of Dr Faust's pact with the devil. Faust's story also provides an example of the longstanding link between the world of the intellect and shadowy occult practices. Faust, a graduate of Wittenberg University, uses his academic knowledge to call up the forces of darkness to further his own intellectual and material ends. As the story of Faust reminds us, academia has long had its morally dubious, even shady side.

Comparably, fuelled by faith in the magic of the market, universities have put themselves at the mercy of free-market capitalism, remaking themselves as marketoriented institutions and emulating corporate models. Indeed, there are metaphorical parallels between pacts with various wealth-giving spirits and the situation in which present-day market-oriented universities find themselves, having wedded themselves to market forces in the hope that this will bring about economic and institutional security. In the Eastern Cape region of South Africa, for example, it is said that an individual may enter into a pact with a mamlambo, a being that bestows wealth at a terrible price, inflicting great suffering and depriving its owner of that which he or she holds dear. The Xhosa term for this procedure is ukuthwala (Wood with Lewis; Wood "The Occult, the Erotic"). The wealth-giving Zimbabwean chikwambo also brings about destruction. Similarly, in parts of West Africa it is believed that those who enter into a wealth-giving pact with a Mami Wata spirit may face may face hazards as their lives become controlled by this being (Wood "Faustian Pacts").

Comparably, market-driven universities in South Africa and elsewhere have succumbed to the neocolonial agenda of globalised neoliberalism which promises profits that come at a price. As East African academic and activist Issa Shivji (34) notes, it seeks to colonise education by subjugating it to corporate, "free" market capitalist imperatives (see also Nash 9; Zeleza and Olukoshi 2-4).

Nowadays, many universities tend to feel that their positions are precarious ones, and their future prospects are uncertain, as far as student numbers, status, funding and their continued survival are concerned. (Sources of funding may vary from country to country, and sometimes from institution to institution.) To varying degrees 
and in various respects, numerous universities worldwide feel insecure, even embattled, as do their employees. These conditions have been intensified by the climate of competitiveness that pervades higher education, infecting both universities and the people within them. Certain concepts of witchcraft in South Africa and elsewhere illuminate the unhealthy nature of this stress-laden competitiveness and the climate of mistrust it engenders; and the general atmosphere of fear and insecurity prevalent at local universities and in other countries in which comparable pressures towards marketisation and corporatisation are at work.

In part, the closed, seemingly close-knit nature of the university environment may sometimes have bearing on this.

\section{The sinister side of kinship and collegiality}

Various significant studies of witchcraft in Africa draw attention to the links between witchcraft and kinship. Indeed, when people live close beside one another, the possibility of friction is heightened. This is also applicable to those who share the same workplace, where interpersonal tensions inevitably arise. Such conditions are exacerbated in the present-day corporate university, subject as it is to many tensions and pressures. Consequently, bonds of various kinds may collapse under the strain. Meanwhile, within the family, the most intimate environment of all, diverse forms of ill-will and anger are particularly prone to arise. In his study of witchcraft in Limpopo, South Africa, Isak Niehaus alludes to the potential for conflict amongst those in close proximity, commenting on the tension between the ideals "of kinship loyalty and agnatic and neighbourly harmony" and the potential for friction between those "locked together in bonds of mutual obligation" (57). This could, by extension be applied to academic collegiality: part professional guild, partly a sharing of the same intellectual neighbourhood, and partly stemming from a sense of belonging to an academic family of a kind. Éric de Rosny (1992) mentions a Duala aphorism from the Cameroonian coast: "One must learn to live with one's own sorcerer" (cited in Geschiere 42). Symbolically, this may apply to many different families, be they biological or professional.

"Witchcraft" Geschiere contends, "is the dark side of kinship [...] It expresses the frightening realisation that aggression threatens from within the intimacy of the family - that is, from the very space where complete solidarity and trust should reign without fail." Consequently, someone may be accused of bewitching one of his or her own family members by his or her own kin. Geschiere describes how concepts of kinship have been extended in many contemporary African societies, particularly on account of factors such as urbanisation. Thus, notions of kinship can now incorporate individuals with whom someone is connected by other than familial ties. Some significant linkages may be established through professional connections, or through 
involvement in civic structures, church groupings, sporting bodies and other social and community networks (Geschiere 212-13). In the light of these redefinitions of the concept of kinship, academic colleagues are, symbolically speaking, kin to one another (Wood "Sorcery"). ${ }^{4}$ Concepts of African kinship, Geschiere contends, are closely related to social security (213-14). In theory, the contemporary workplace is a source of this (although actual events may prove otherwise). For that reason, too, professional colleagues may come to seem like family of a kind.

The limitations of such assumptions soon become apparent. Family bonds and other close connections may be placed under strain or be broken by certain turns of events; and symbolic forms of kinship are far more easily severed. This may take place in the university milieu when specific academics are required to serve as agents of managerial control. Thus, they may possibly become directly or indirectly responsible for destabilising the lives of their colleagues.

For example, UK academics Chris Shore and Susan Wright describe how internal audits draw staff into policing roles through their involvement in university structures and committees in which areas such as performance, accountability and quality are measured (566). Meanwhile, former academics who have "crossed over to the managerial dark side" (Taylor 1), or those luckless academic staff in positions of middle management (such as heads of departments) are now required to monitor the performances of the employees over whom they preside. As a result, university staff are under ongoing scrutiny from one another, and an individual may be accused of unprocedural academic practices by her or his former colleagues, or academic kin (Wood "Sorcery"). Metaphorically speaking, they have become drawn into the process of institutional witchfinding.

\section{Covetousness, competition and consumption}

The metaphorical parallels between perceptions of witchcraft and contemporary corporatised academia extend beyond kinship. Witchcraft is sometimes believed to spring from specific urges and cravings, and present-day market-driven academic discourse and practice may often seem to be driven by comparable tendencies. In certain parts of South Africa the belief prevails that greed, covetousness and the selfish hoarding of individual material resources can be associated with dangerous supernatural forces. Adam Ashforth's Soweto respondents, for example, maintained that jealousy was the principal cause of witchcraft, as have many other individuals and communities in diverse parts of Africa (Ashforth 521; also Evans-Pritchard 55, 80; Geschiere 212). Ashforth's respondents used the term "jealousy" to denote not only envy of the material well-being of others, but also the urge to "jealously guard" one's own wealth and possessions, and bar others from sharing them (521). Comparable tendencies have come to characterise contemporary neoliberal, market-oriented 
environments, universities included. As University of the Witwatersrand researcher Salim Vally observes, "Individualism, competition and consumption are the dominant values within academe as elsewhere" (23).

We have already noted that universities were hardly idyllic places in the past, subject as they were to cronyism, elitism, jealousy and scheming at both academic and at administrative levels. However, as numerous commentators remind us, managerial systems have changed, as have many academic environments. Now, headed by vice-chancellors remade as pseudo-CEOs, senior managers remould institutional structures, procedures and discourses and cultures in the image of those of the corporate sector (Ginsberg; Collini; Olssen and Peters 327, 329).

In the process, "a discourse of [...] competitiveness" (Vally 17) has come to the fore at managerial and state level, emanating from the notion that fomenting rivalry and divisions of this nature is constructive, contributing to the expansion of the knowledge economy and enabling universities to compete more effectively in global markets. Notions of this kind are reshaping the culture of the academic workplace.

Nowadays, many corporatised universities worldwide "are infused with a deeply rooted competitive individualism, promoted at almost every point" (Grossman, 100). In 1999, for example, the University of Witwatersrand emphasized in its Strategic Plan that the university would need to compete with other institutions for staff, students and sources of funding (cited in Pendlebury and van der Walt 82). In the UK in 1996, a Research and Development Report noted that "to a much greater extent than ever previously, universities must now compete with each other for resources" (Greene, Loughridge and Wilson 4). Comparable pressures are prevalent in marketoriented universities worldwide (for example Orr 54). As many local and international commentators observe, this competition for limited economic and material resources takes place not only between institutions, but extends right into the heart of universities themselves, permeating faculties, schools and departments, and generating tensions between individuals (for example Shore and Wright 559).

Consequently, as Cambridge academic Stefan Collini puts it, "the glib assumption that universities are locked in combat with each other in some form of worldwide competition" now constitutes one of the dominant notions in academia, infecting many universities in the UK and elsewhere: "In Britain, the discussion mostly reduces to whether Oxford and Cambridge and Imperial College are "competing with Harvard and Stanford and MIT; in certain other countries, attention is focused on getting one or more universities in the world's 'top 50' or 'top 100'" (Collini 17-18).

Academic competition may take different forms in diverse countries, and degrees of profit and prestige accruing from this may be subject to variation. Yet some comparable pressures prevail. In South Africa, for instance, the University of the Witwatersrand is seeking to displace the University of Cape Town (UCT) as Africa's foremost tertiary institution (Govender 13). 
Shore and Wright observe that various forms of rivalry are intensified by the audit system, with its accompanying performance indicators:

The new audit norms focus on adherence to selective performance indicators to produce a quantifiable score that is then used as the basis for pitting department against department and institution against institution. Thus a pecking order is created between those departments ranked as 3,4 , and $5^{*}$ ('international excellence'). Increasingly that ranking system is also being applied informally to individuals, thus creating new ways of conceptualizing colleagues as, for example, 'a $3 b^{\prime}$ ', or a ' 5 ' researcher" (Shore and Wright 569).

In South Africa, the ratings bestowed on researchers by the NRF perform similar functions. (NRF ratings are partly determined by factors such as publications, patents, other measurable research outputs and impact thereof, and postgraduate student supervision.) These ratings and certain measurable, officially approved research outputs such as publications and patents, reap monetary rewards, as do numbers of graduates, particularly at postgraduate level. Universities receive state funding on the basis of these; and the faculties and departments in question tend to benefit financially in turn (Ministerial Statement 2012/3 and 2013/4). Moreover, many institutions tend to award cash incentives to academics for publications and the graduation of postgraduate students under their supervision. Meanwhile, NRF-rated researchers have access to special funding sources. These monetary incentives heighten academic rivalry at various levels.

University rankings embody this competiveness, as does the discourse often employed to depict them. Featuring headlines like "Why the University of Surrey is on the Rise", "SA Varsities Slip Down in Global Rankings" and "UCT drops 13 places on World University Rankings", it sometimes evokes sports event commentaries or stock market reports. In the UK, university rankings are often referred to as "League Tables": lists displaying the current standing of sports teams. University rankings are based significantly on research assessments; also on factors like student-staff ratios, graduate career prospects, institutional resources and perceived prestige of universities.

Collini depicts the greed, suspicion and selfishness that this climate of competitiveness has fostered. Many universities may now come to perceive other institutions as their opponents in an ongoing struggle for prestige, institutional security and ever-diminishing resources. This kind of "educational Darwinism" breeds mistrust and tension (Collini 163). The dominance of the self-seeking, competition-oriented mindset to which Collini and the above-cited commentators allude is indicative of the extent to which many universities world wide have become submerged in a winnertakes-all capitalist ethos. Tendencies of this kind have certain metaphorical echoes with the selfish craving for individual material accumulation at all costs, often obtained 
by means of others' misfortunes, that is said to characterise practitioners of witchcraft (Geschiere 5, 16; Niehaus 9).

The sense of stress and desperation permeating many market-driven universities fuels the compulsion to accrue that which may safeguard them in troubled times. Both locally and internationally, many contemporary universities tend to labour under increasing pressures and material constraints, with the ever-present threats of funding cuts, retrenchments and closures of departments or entire institutions looming over their daily day-to-day activities. Numerous employees are also placed under pressures of various kinds, as the spectres of quality, accountability, excellence, performance and efficiency hover over their day-to-day working lives. Conditions of this nature can intensify the desire to accumulate that which will bestow individual, departmental and institutional material security. This may often manifest itself in a preoccupation with scores, ratings and ranking levels, and points bestowed on individuals, departments and institutions by internal and external assessors. Such tendencies often heighten a resentful awareness of others' advantages; while also fostering insecurity, envious rivalry and covetousness. Thus, an anxiety to excel—even, if need be, at the cost of other departments, divisions, or institutions-is combined with a fear of the possible consequences of failure (for instance Shore and Wright 569).

While the malevolence of witchcraft may differ in depth and intensity from the damaging tendencies that the market-driven university environment has brought to the fore, various metaphorical parallels are worth considering. Oxford academic Danny Dorling makes a pertinent point, maintaining that present-day social and economic injustice is validated and perpetuated by means of several interconnected, widespread notions. First, elitism is equated with efficiency, and exclusion and prejudice are normalised. Next, greed is valorized; while despair is depicted as inevitable (cited in Amsler 6). In certain respects, these forms of selfishness, avarice and arrogance manifest themselves in the market-oriented university milieu, with its emphasis on competitiveness and the-winner-takes-all capitalist ethos. Here, as elsewhere, privatisation and individual accumulation is promoted. This may perhaps call to mind two interconnnected, opposing impetuses in sorcery: accumulation and deprivation. Contemporary witchcraft practitioners, we have already noted, are driven by an urge to gather and guard that will provide material well-being, generally obtained at the cost of others.

Moreover, the present-day academic climate of competitiveness can foster ill-will, encouraging malicious impulses. Some may wish misfortune on others, seeking to benefit from this, and may attempt to do them damage in other respects. For instance, some employees and managers may be gladdened when certain institutions, departments or colleagues suffer setbacks or calamities, if the disadvantages of others may work to their advantage. While such malicious tendencies long been features of academia, the present-day market-driven university environment, with its focus on competitiveness, lends itself particularly to harmful inclinations of this kind. 
It is worth noting that witchcraft is not always perceived as an act of conscious malice by certain individuals in Africa. For instance, some of E. E. Evans-Pritchard's Azande respondents in South Sudan maintained that some witches were capable of acting without a full awareness of their destructive intentions (56-60). Arguably, perhaps, some employees at corporatised universities may not always be fully aware of the extent to which they may damage the professional and personal lives of others by means of their utterances and actions.

Nonetheless, much harm can be inflicted in the course of many of the routine procedures and processes in the corporate university milieu. For example, audits and other external and internal forms of evaluation and monitoring sometimes offer opportunities to highlight the shortcomings and failings of others, whether actual or imagined. (At such times, for instance, certain departments may perhaps be deemed to be overstaffed or non-viable; while specific employees' performances may be found wanting.) Then, since market-driven universities attach considerable importance to neoliberal economic practices like cost-cutting and rationalisation, further damage can be done to individuals, departments and institutions by these means. The negative incentives now prevalent at many market-driven universities may also provide ample opportunities for inflicting harm. Disciplinary codes of conduct often tend to be emphasised and attention is drawn to the punitive measures levelled against those who transgress them (Thornton 163-64). Those who preside over institutional hierarchies may also seek to exact compliance from their subordinates, partly by imposing targets which they may be ill-equipped to meet, and partly by threats, some veiled and some overt, of imposing punitive measures should they be judged and found wanting (see for example Olssen and Peters 320; Thornton 161). There is a connection, various commentators observe, between the autocratic nature of the managerialised university, and the new forms of authoritarianism that characterise the corporate sector (Thornton 161, 163-64, 174; Vale 4; Wood "Sorcery").

Incidentally, various occult practitioners in South Africa and elsewhere are said to make use of some comparable strategies to draw attention to their powers (Wood and Lewis). For instance, Evans-Pritchard observes that those who make unpleasant allusions to others, or threaten them with misfortune should they displease them are often suspected of witchcraft among the Azande (51). Furthermore, both menacing manifestations of the occult and various university managers may display a certain degree of vindictiveness. This appears to be an essential attribute of malign occult beings; and the "corporate authoritarianism" manifested in the present-day university environment sometimes involves bullying tactics, which can slide all too easily into spitefulness and malice (Southall and Cobbing 13; Thornton 161-64). Consequently, some staff members live in such dread of incurring the displeasure of their university managements that that they may appear comparable to individuals who constantly fear arousing the wrath of witches and other unpredictable, potentially malign occult forces. 
The corporate university environment encourages the growth of damaging tendencies in other, related respects. Images of consumption can characterise malevolent occult agencies, and African witches are often renowned for their obsession with eating. Thus, witchcraft is often perceived as a form of spiritual and psychological devouring (Geschiere 203; Bastian 133; Schmoll 193-220). The mamlambo, for example, devours blood: literally the blood sacrifices it requires; and metaphorically speaking, the hearts-blood of those who are bound to it (Wood "Faustian Pacts"). ${ }^{5}$ There are, moreover, certain points of comparison between this occult urge to consume and the present-day spirit of consumerism that has come to characterise many market-driven higher education environments. In the global knowledge economy, students are the consumers, higher education is a consumer good, and academics the human capital feeding consumer forces.

As a result of these above-outlined factors, it could be contended that restructured, market-driven universities that have taken on the procedures and practices of the corporate capitalist workplace have entered a hazardous realm, within which potentially damaging forces, both mercantile and metaphorically magical, wield sway at both seen and unseen levels.

\section{Consequences and sacrifices}

Georg Simmel draws attention to the extent to which economic exchange can be characterised by sacrifices, for an individual who desires an object may be required to relinquish something that is dear to her or him (cited in Appadurai 3-4). Simmel's point acquires a growing resonance in the corporatised university context. Just as a mamlambo demands that its owner sacrifice those dearest to him or her in order to obtain an ongoing supply of wealth and avoid the punishments that might otherwise befall them, so many universities are required to sacrifice that which was, in essence, closest to their hearts: the workplace ethos that make for effective teaching and research. Thus, like an ukuthwala pact with a mamlambo, universities' uneasy alliances with the corporate world are sustainable only if they strike at their souls. For instance, Adèle Thomas, from the University of Johannesburg, argues that many universities' ability to affirm and maintain an ethical culture has been eroded because universities now copy corporate practice, which tends to focus on results, rather than values (4-5). Meanwhile, Mahmood Mamdani (76) describes how Makerere University, Uganda, has been "systematically soiled by a market ethic", with staff becoming contaminated by greed (Wood "Sorcery"). His point is widely applicable. Moreover, those who place that which is close to their hearts, their own academic ideals, before managerial decrees and the pursuit of corporate goals, place themselves at risk (Wood "Faustian Pacts").

Once again, the story of Faust springs to mind. Marlowe's Faust, we recall, enters into a pact with commercial as well as spiritual aspects, like the owner of a mamlambo, 
selling his soul to further his own intellectual ends. However, like a mamlambo's consort, he does not benefit from the transaction. During the rest of his career, he does not prosper as he sought to do. He desires to enhance the store of earthly knowledge by embarking on his pact, yet significantly, one of the areas in which his failure is particularly evident is that of knowledge production (Wood "Faustian Pacts").

Therefore, that which Mamdani (76) describes as the "market morality of profit" now tends to direct the nature and purpose of much academic work. In part, the yearning for success and economic well-being is potentially dangerous because it can become a predominant force driving academic practice. Sometimes, desires of this nature may seem all-consuming, engulfing the lives of those individuals who become entrapped by them and the environments they inhabit. It is said that those who take on the ownership of a mamlambo are reduced to a similar state.

Just as the owner of a mamlambo is driven by an overriding desire for wealth, so market-oriented, corporatised universities pursue economic profit above all else. They pay a high price for this, partly because this can often constrain and conflict with the essential life of academia. Moreover, as the parallels with sinister aspects of the supernatural suggest, this can contaminate university environments, reducing them to places of sorrow and fear, in which forms of envy, suspicion, self-centredness and greed run rampant, fuelled by the forms of market-driven corporate capitalism that universities have embraced.

\section{Acknowledgements}

I am indebted to Sylvia Tloti, who worked with me for years as my research assistant, for her contribution to my research into the figure of the mamlambo and the $u$ kuthwala processes. My recent student researchers at the University of Fort Hare, Wendy Muswaka and Abbey Alao, also contributed many of the interviews and personal narratives upon which this paper draws. I am grateful to Michael Lewis for sharing his research on the mamlambo and the ukuthwala processes with me. The University of Fort Hare and the National Research Foundation provided funding for this research.

\section{Notes}

1. This paper forms part of a broader research project investigating the occult aspects of contemporary academia. Three articles exploring other occult features of market-oriented universities also form components of this (see Wood "Occult Innovations", "Sorcery", "Faustian Pacts").

2. Much of the information in this paper concerning the ownership of a mamlambo, other wealthgiving spirits and perceptions of the sinister side of the southern and West African supernatural derives from a series of interviews conducted between 1997 and 2010 in the Eastern Cape, KwaZuluNatal, Nigeria and Lesotho by Felicity Wood, Sylvia Tloti, Wendy Muswaka, Abbey Alao and Michael Lewis (see Acknowledgements). Some respondents interviewed had known certain ukuthwala practitioners, or members of their extended families or communities had undergone ukuthwala. Other respondents had received information from older people who knew much about the mamlambo, or other forms of wealth-giving magic or perceptions of witchcraft; or lived in communities in which many accounts of such matters had been related.

3. "Witchcraft" is a problematic term, carrying with it a strong sense of moral condemnation. Moreover, translating diverse local African terms as "witchcraft" can be reductive and misleading, since the original notions may be complex and ambiguous, possessing a diversity of meanings (Geschiere 13-14). Notwithstanding this, this term is utilised here, since it is used by various anthropologists and diverse African communities (for example Moore and Sanders 3, and Geschiere 12-15). 
4. The points in this and the following paragraph (and, where indicated, elsewhere in this paper) also appear in another study analysing other occult dimensions of contemporary higher education, but also mentioning the issue of witchcraft and kinship (Wood "Sorcery").

5. The points made here (and elsewhere, where indicated) appear in another article on the occult aspects of marketised academia (Wood "Faustian Pacts").

\section{Works Cited}

Amsler, Sarah. "University Ranking: a dialogue on turning towards alternatives". Ethics in Science and Environmental Politics 13 (2013): 3-14.

Appadurai, Arjun. The Social Life of Things: Commodities in Cultural Perspective. Cambridge: CUP, 1986.

Ashforth, Adam. "On Living in a World with Witches: everyday epistemology and spiritual insecurity in a modern African city (Soweto)". Magical Interpretations, Material Realities: Modernity, Witchcraft and the Occult in Postcolonial Africa. Eds. Moore, Henrietta L. and Todd Sanders. London and New York: Routledge (2001): 206-25.

Bastian, Misty. "Bloodhounds Who Have No Friends: Witchcraft and Locality in the Nigerian Popular Press". Modernity and Its Malcontents: Ritual And Power In Postcolonial Africa. Eds. Comaroff, Jean and John. Chicago and London: U Chicago P, 1993, 129-66.

Buchbinder, Howard. "The Market Oriented University and the Changing Role of Knowledge." Higher Education 26.3 (1993): 331-47.

Collini, Stefan. What Are Universities For? London: Penguin, 2012.

Comaroff, Jean. Body of Power, Spirit of Resistance: The Culture and History of a South African People. Chicago: U Chicago P, 1985.

Comaroff, Jean and John. "Occult Economies and the Violence of Abstraction: Notes from the South African Postcolony." American Ethnologist 26.2 (1999): 279-303.

Evans-Pritchard, E. E. Witchcraft. Oracles and Magic among the Azande. Oxford: Clarendon, 1976.

Fisiy, Cyprian F. and Peter Geschiere. "Witchcraft, Development and Paranoia in Cameroon: Interactions between Popular, Academic and State Discourse." Magical Interpretations, Material Realities, Modernity, Witchcraft, and the Occult in Postcolonial Africa. Eds. Henrietta Moore and Todd Sanders. London and New York: Routledge, 2001. 226-46.

Geschiere, Peter. The Modernity of Witchcraft: Politics and the Occult in Postcolonial Africa. Charlottesville: U Virginia P, 1997.

Ginsberg, Benjamin. The Fall of the Faculty. Oxford: OUP, 2011.

Govender, Prega. "Wits Ready to Spend Big to Get to First Place." Sunday Times 6 October (2011): 13.

Greene, Francis, Brendan Loughridge and Tom Wilson. "Models of University Organisation: from the Platonic Academy to the Commercial Mall." Extract from The Management Information Needs of Academic Heads of Departments in Universities: A Critical Success Factors Approach British Library Research and Development Report 6252 (1996). 12 Dec. 2009. <http://informationr.net/ tdw/publ/hodsin/Chap02.html>.

Grossman, Jonathon. "World Bank Thinking, World-class Institution, Denigrated Workers". Ed. Richard Pithouse. Asinamali: University Struggles in Post-Apartheid South Africa. Trenton and Asmara: Africa World Press, 2006. 93-105.

Mamdani, Mahmood. Scholars In The Marketplace: The Dilemmas of Neo-Liberal Reform at Makerere University, 1989-2005. Dakar: Codesria, 2007.

Moore, Henrietta and Todd Sanders. "Magical Interpretations and Material Realities: An Introduction". Magical Interpretations, Material Realities, Modernity, Witchcraft, and the Occult in Postcolonial Africa. Eds. Henrietta Moore and Todd Sanders. London and New York: Routledge, 2001. 1-27.

Nash, Andrew. "Restructuring South African Universities". Asinamali: University Struggles in PostApartheid South Africa. Ed. Richard Pithouse. Asmara: Africa World Press, 2006. 1-10.

Niehaus, Isak. Witchcraft, Power and Politics: Exploring the Occult in the South African Lowveld. Cape Town: David Philip; London: Pluto, 2001.

Olssen, Mark and Michael A. Peters. "Neoliberalism, Higher Education and the Knowledge Economy: From the Free Market to Knowledge Capitalism". Journal of Education Policy 20.3 (2005): 313-45.

Orr, Liesl. "Globalisation and Universities: Towards 'the Market University'?". Social Dynamics 23 (1997): $42-67$. 
Pendlebury, James and Lucien van der Walt. "Neoliberalism, Bureaucracy and Resistance at Wits University". Asinamali: University Struggles in Post-Apartheid South Africa. Ed. Richard Pithouse. Asmara: Africa World Press, 2006. 79-92.

Schmoll, Pamela G. Black Stomachs. "Beautiful Stones: Soul-eating among Hausa in Niger". Modernity and Its Malcontents: Ritual and Power in Postcolonial Africa. Eds. Jean and John Comaroff. Chicago and London: U Chicago P, 1993. 193-220.

Shivji, Issa G. "Wither University: education as market fantasy or education as public good?". Quarterly Review of Education and Training in South Africa 1.12 (2005): 34-37.

Shore, Chris and Susan Wright. "Audit Culture and Anthropology: Neoliberalism in British Higher Education". Journal of the Royal Anthropological Institute 5 (1999): 557-73.

Southall, Roger and Julian Cobbing. "From Racial Liberalism to Corporate Authoritarianism: The Shell affair and the assault on academic freedom in South Africa". Social Dynamics 27.2 (2001): 1-31.

Taylor, Paul. "Humboldt's Rift: Managerialism in Education and Complicit intellectuals". European Political Science Autumn 3 (2003): 1-7.

Thomas, Adèle. "Ethics and Morality Suffer". Mail \& Guardian: Higher Learning, 20 February (2009).

Thornton, Margaret. "Corrosive Leadership (Or Bullying by Another Name): a corollary of the corporatised academy?". Australian Journal of Labour Law 1.2 (2004): 161-84.

Trice, Harrison M. and Janice M. Beyer. "Studying Organisational Cultures through Rites and Ceremonials". The Academy of Management Review 9.4 (1984): 653-69.

Vale, Peter. "Servants or Savants". Mail \& Guardian: Getting Ahead. 6 Feb (2009).

Vally, Salim. "Higher Education in South Africa: Market Mill or Public Good?". Council for the Development of Social Science Research in South Africa 5. 1 (2007): 17-28.

Wood, Felicity. "Faustian Pacts and False Promises: the mamlambo and the market university". Southern African Journal for Folklore Studies (forthcoming).

- "Occult Innovations in Higher Education: Corporate Magic and the Mysteries of Managerialism". Prometheus: Critical Studies in Innovation 28.3 (2010): 227-44.

. "Sorcery in the Academy: Universities and the Occult Rituals of the Corporate World". Southern African Journal for Folklore Studies 1 (2010): 4-28.

- "The Occult, the Erotic and Entrepreneurship: An Analysis of Oral Accounts of Ukuthwala, Wealth-Giving Magic, sold by the Medicine Man Khotso Sethuntsa". Alternation 15.1 (2008) 338-66.

- with Michael Lewis. The Extraordinary Khotso: Millionaire Medicine Man of Lusikisiki. Johannesburg: Jacana, 2007.

Zeleza, Paul Tiyambe and Adebayo Olukoshi. "Introduction: The Struggle for African Universities and Knowledges." African Universities in the Twenty-First Century: Volume 1: Liberalisation and Internationalisation. Eds. Zeleza and Olukoshi. Dakar: CODESRIA (2004). 1-18. 